\title{
HUBUNGAN PERILAKU DENGAN MOTIVASI KEHADIRAN IBU DALAM PENYULUHAN GIZI BALITA
}

\author{
Safrizal.SA ${ }^{1}$, Zakiyuddin ${ }^{2}$ \\ Fakultas Kesehatan Masyarakat Universitas Teuku Umar \\ friza.maulanaboet@gmail.com¹, zakiyuddin@utu.ac.id²
}

\begin{abstract}
ABSTRAK
Motivasi adalah suatu kecenderungan yang timbul pada diri ibu untuk secara sadar menghadiri penyuluhan tentang pemenuhan gizi pada balita. Berdasarkan data menunjukkan bahwa kehadiran ibu balita dalam penyuluhan gizi dari jumlah ibu sebanyak 4.764 diketahui jumlah kesertaan ibu mengikuti kegiatan penyuluhan gizi mencapai $3.598 \mathrm{ibu}(75,0 \%)$. kunjungan tertinggi berada pada bulan November mencapai 437 balita dan terendah berada pada bulan maret mencapai 371 balita. Ada 22 Posyandu di wilayah kerja Puskesmas Johan Pahlawan yang melakukan penyuluhan, pelaksanaanya dalam setahun 3 kali dan dilaksankan pada setiap bulan April. Tujuan penelitian ini adalah untuk mengetahui hubungan perilaku ibu dengan motivasi kehadiran ibu dalam penyuluhan gizi balita. Penelitian ini menggunakan jenis survey analitik dengan rancangan cross sectional. Populasi 4.764 ibu balita. Pengambilan sampel menggunakan teknik purposive berjumlah 98 ibu balita pada tahun 2016. Analisis data penelitian menggunakan uji chi-square. Hasil penelitian menunjukkan bahwa ada hubungan variabel pengetahuan (P.Value $=0,013$ dan $R P=3,1$ ), sikap $(P$. Value $=0,001$ dan $R P=4,2)$ dukungan keluarga $(P$. Value $=0,040$ dan $R P=4,6)$ dan peran tenaga kesehatan ( $P$. Value $=0,001$ dan $R P=4,5)$. Kesimpulan penelitian ada hubungan pengetahuan, sikap, dukungan keluarga, dan peran tenaga kesehatan dengan motivasi kehadiran ibu balita dalam penyuluhan gizi. Disarankan kepada ibu untuk dapat membawa balita ke fasiltas kesehatan agar memberikan gizi kepada balita. Kepada kader kesehatan agar dapat mensosialisasikan pemberian gizi balita.
\end{abstract}

\section{Kata Kunci: Perilaku, Motivasi, Penyuluhan, Gizi, Balita}

\section{PENDAHULUAN}

Penyuluhan gizi merupakan salah satu upaya pendekatan yang dapat dilakukan untuk meningkatkan pengetahuan sehingga menghasilkan perubahan perilaku yang baik. Dengan adanya penyuluhan gizi diharapkan Ibu balita mengerti dan memahami serta mau dan mampu melaksanakan apa yang dinasehatkan sehingga mampu mengasuh dan merawat balita gizi kurang menjadi lebih baik (Kemenkes RI, 2012).
Pemberian gizi berperan besar terhadap penurunan angka kematian bayi dan menurunkan pravelensi gizi kurang pada anak balita. Pada tahun 2010 dari Laporan WHO (World Health Organization) mencatat bahwa $60 \%$ kematian balita secara tidak langsung disebabkan oleh kurang gizi dan 2/3 kematian tersebut terkait praktek pemberian makanan yang kurang tepat (WHO, 2011).

Di Indonesia cakupan pelayanan kesehatan bayi dapat menggambarkan upaya pemerintah dalam meningkatan 
akses balita untuk memperoleh pelayanan kesehatan dasar, mengetahui sedini mungkin adanya kelainan atau penyakit, pemeliharaan kesehatan dan pencegahan penyakit, serta peningkatan kualitas hidup bayi. Gambaran capaian indikator ini di 33 provinsi menunjukkan bahwa sebanyak 13 provinsi $(39,39 \%)$ telah memenuhi target Renstra tahun 2014 yaitu sebesar $90 \%$ (Kemenkes RI, 2015)

Provinsi Aceh diketahui prevalensi gizi kurang 15,8\% dan gizi buruk 10,4\%. Sedangkan pada tahun 2012 berdasarkan laporan Dinas Kesehatan Provinsi Aceh bahwa terdapat $18 \%$ (7.002) balita di Aceh masih menderita gizi kurang dan buruk, dari jumlah 38.900 balita (Profil Kesehatan Provinsi Aceh, 2012). Selanjutnya pada tahun 2014 menunjukkan capaian indikator pelayanan kesehatan balita yang mendapat pelayanan minimal 8 kali sebesar $74 \%$ yaitu sebanyak 298.476 balita. Berdasarkan estimasi data secara keseluruhan jumlah balita di Aceh pada tahun 2014 sebanyak 393.743 balita. Berkaitan dengan kasus gizi buruk pada balita pada tahun 2014 ditemukan ada 366 kasus dan semua penderita mendapat perawatan (Profil Kesehatan Provinsi Aceh, 2014).

Di Kabupaten Aceh Barat bahwa pelayanan kesehatan pada balita 12-59 bulan harus memperoleh pelayanan standar yang meliputi; pemantauan terhadap pertumbuhan balita minimal 8 kali dalam setahun, pemantauan perkembangan balita minimal 2 kali dalam setahun, dan pemberian vitamin A minimal 2 kali dalam setahun. Adapun cakupan pelayanan pada balita pada tahun 2013 sebanyak 10.321, tahun 2015 sebanyak 11.833 dan tahun 2016 sebanyak 11.691. Target cakupan ini masih rendah karena belum mencapat target yang ditetapkan oleh pemerintah sebesar $90 \%$. Selanjutnya kasus gizi buruk di Kabupaten Aceh Barat ditemukan sebanyak 19 kasus dan mendapat perawatan sebanyak 19 balita (100\%) (Dinas Kesehatan Kabupaten Aceh Barat, 2017).

Menyangkut

dengan

pemantauan kesehatan pada balita terhadap 13 Puskesmas di Kabupaten Aceh Barat menunjukkan bahwa puskesmas yang melayani kesehatan balita dengan cakupan tertinggi adalah Puskesmas Johan Pahlawan sebesar $73.3 \%$ sedangkan yang paling rendah adalah Puskesmas Meureubo sebesar 50, $4 \%$. Adapun cakupan balita BGM tertinggi terdapat di Puskesmas Johan Pahlawan sebanyak 88 balita dan balita BGM terendah Drien Rampak, Pancer dan Pasi Mali sebanyak 0 balita.

Di Wilayah Kerja Puskesmas Johan Pahlawan Kabupaten Aceh Barat, pelayanan kesehatan pada balita usia 1259 bulan secara keseluruhan pada tahun 2014 terdata ada 3.885 balita, sedangkan balita yang mendapat pelayanan kesehatan minimal 8 kali berjumlah 2.846 (73.3) \% atau masih belum mencapai target yang ditetapkan Puskesmas sebesar $90 \%$ (Puskesmas Johan Pahlawan, 2014). Sedangkan pada tahun 2015 terdata ada 5.143 balita, sedangkan yang mendapat pelayanan kesehatan minimal 8 kali berjumlah $4.790(93.1 \%)$ atau masih belum mencapai target yang ditetapkan Puskesmas sebesar $100 \%$. Berdasarkan data juga menunjukkan terdapat 1 balita yang menderita gizi buruk dan $16(0.3$ \%) balita yang mengalami gizi kurang, dan terdapat $88(1.8 \%)$ balita di bawah garis merah (BGM) (Puskesmas Johan Pahlawan, 2015).

Mengenai cakupan kunjungan balita setiap bulannya mencapai 399 balita perbulan. Dari data diperoleh 
bahwa kunjungan tertinggi berada pada bulan November mencapai 437 balita dan terendah berada pada bulan maret mencapai 371 balita. Menyangkut dengan penyuluhan gizi yang dilakukan oleh Puskesmas Johan Pahlawan dilakukan oleh 22 Posyandu setiap 4 bulan sekali atau 3 kali dalam setahun. Dari jumlah ibu sebanyak 4.764 diketahui jumlah kesertaan ibu mengikuti kegiatan penyuluhan gizi mencapai 3.598 ibu (75.5\%). (Puskesmas Johan Pahlawan, 2015). Masih rendahnya kunjungan ibu untuk menghadiri penyuluhan gizi dari survey awal yang peneliti lakukan terhadap 10 orang $\mathrm{ibu}$ balita di Puskesmas Johan Pahlawan bahwa masih terdapat 4 orang ibu yang tidak mengetahui manfaat dari penyuluhan gizi, 2 orang ibu tidak pernah ikut penyuluhan gizi karena tidak mendapat informasi yang lengkap tentang penyuluhan gizi baik dari ibu lain atau dari tenaga kesehatan dan terdapat 3 orang ibu yang kurang mendapat dukungan dari suami.

Rendahnya kunjungan ibu untuk menghadiri penyuluhan dari 10 orang ibu tersebut dilihat dari pengetahuannya yang masih kurang dikarenakan ibu tidak pernah mendapatkan informasi mengenai manfaat, tujuan dan jadwal kunjungan gizi baik dari ibu lain yang datang ke penyuluhan gizi maupun dari tenaga kesehatan puskesmas. Rendahnya pengetahuan ibu memungkinkan timbulnya sikap ibu negatif bahwa pergi ke penyuluhan gizi menjadi tidak penting. Sebab lain rendahnya kunjungan ibu ke penyuluhan gizi, juga dikarenakan dukungan keluarga masih kurang, karena dari keluarga dianggap telah mengetahui tentang gizi yang diberikan kepada balita. Sebab lain adalah kurangnya peran tenaga kesehatan yang melakukan kunjungan ke rumah-rumah ibu balita untuk memberikan informasi mengenai penyuluhan gizi.

\section{METODE}

Penelitian ini menggunakan jenis survey analitik dengan rancangan cross sectional. Populasi 4.764 ibu balita. Pengambilan sampel menggunakan teknik purposive berjumlah $98 \mathrm{ibu}$ balita pada tahun 2016. Analisis data penelitian menggunakan uji chi-square.

\section{HASIL}

\section{Hubungan Pengetahuan dengan Motivasi Kehadiran Ibu dalam Penyuluhan Gizi Balita}

\begin{tabular}{|c|c|c|c|c|c|c|c|}
\hline \multirow{3}{*}{ Pengetahuan } & \multicolumn{4}{|c|}{ Motivasi } & \multirow{2}{*}{\multicolumn{2}{|c|}{ Jumlah }} & \multirow{3}{*}{ P. Value $=0,013$} \\
\hline & \multicolumn{2}{|c|}{ Positif } & \multicolumn{2}{|c|}{ Negatif } & & & \\
\hline & $\mathrm{n}$ & $\%$ & $\mathrm{n}$ & $\%$ & f & $\%$ & \\
\hline Baik & 25 & 58,1 & 18 & 41,9 & 43 & 100 & $\begin{array}{l}\mathrm{RP}=3,1 \\
(1,3-7,1)\end{array}$ \\
\hline
\end{tabular}

\begin{tabular}{ccccc}
\hline Kurang Baik & 17 & 30,9 & 38 & 69,1 \\
$\begin{array}{c}\text { Data Primer, 2016 } \\
\text { Berdasarkan }\end{array}$ & data & & ditabel
\end{tabular}

menunjukkan bahwa dari 43 responden berpengetahuan Baik dan memimiliki motivasi positif sebanyak $25(58,1)$, dan $18(41,9)$ responden yang bermotivasi negative. Dari 55 responden yang berpengetahuan kurang baik sebanyak $17 \quad(30,9)$ yang bermotivasi positif dan $38(69,1)$ yang bermotivasi negative.

Ada hubungan Pengetahuan dengan motivasi yang menunjukkan nilai $P$. Value $=0,013$ dan Nilai $R P=3,1$ yang artinya $\mathrm{ibu}$ yang memiliki 
penegtahuan kurang akan berisiko sebesar 3,1 kali tidak hadir dalam penyuluhan gizi dibandingkan dengan ibu yang memiliki pengetahuan baik.

Hubungan Sikap dengan Motivasi Kehadiran Ibu dalam Penyuluhan Gizi Balita

\begin{tabular}{|c|c|c|c|c|c|c|c|}
\hline \multirow{3}{*}{ Sikap } & \multicolumn{4}{|c|}{ Motivasi } & \multirow{2}{*}{\multicolumn{2}{|c|}{ Jumlah }} & \multirow{3}{*}{ P.Value $=0,001$} \\
\hline & \multicolumn{2}{|c|}{ Positif } & \multicolumn{2}{|c|}{ Negatif } & & & \\
\hline & $\mathrm{n}$ & $\%$ & $\mathrm{n}$ & $\%$ & f & $\%$ & \\
\hline Positif & 28 & 60,9 & 18 & 39,1 & 46 & 100 & $\begin{array}{l}\mathrm{RP}=4,2 \\
(1,8-9,8)\end{array}$ \\
\hline Negatif & 14 & 26,9 & 38 & 73,1 & 52 & 100 & \\
\hline
\end{tabular}

\section{Data Primer, 2016}

Berdasarkan data ditabel dari 46 responden bersikap positif dengan motivasi positif sebanyak $28(60,9)$ responden, dan $18 \quad(39,1)$ memiliki motivasi Negatif, dari 52 responden yang bersikap negative memiliki motivasi positif sebanyak $14 \quad(26,9)$ responden dan motivasi negative sebanyak $38(73,1)$ responden. Terdapat hubungan anatara sikap dengan motivasi ibu karna Nilai P.Value $=0,001$. Nilai $\mathrm{RP}=4,2$ menunjukkan sikap merupakan faktor risiko motivasi kehadiran ibu, artinya ibu yang memiliki sikap negatif akan berisiko sebesar 4,2 kali tidak hadir dalam penyuluhan gizi dibandingkan dengan ibu yang memiliki sikap positif.

Hubungan Dukungan Keluarga dengan Motivasi Kehadiran Ibu dalam Penyuluhan Gizi Balita

\begin{tabular}{|c|c|c|c|c|c|c|c|}
\hline \multirow{3}{*}{$\begin{array}{c}\text { Dukungan } \\
\text { Keluarga }\end{array}$} & \multicolumn{4}{|c|}{ Motivasi } & \multirow{2}{*}{\multicolumn{2}{|c|}{ Jumlah }} & \multirow{3}{*}{ P. Value $=0,040$} \\
\hline & \multicolumn{2}{|c|}{ Positif } & \multicolumn{2}{|c|}{ Negatif } & & & \\
\hline & $\mathbf{n}$ & $\%$ & $\mathbf{n}$ & $\%$ & f & $\%$ & \\
\hline Ada & 28 & 52,8 & 25 & 47,2 & 53 & 100 & $\mathrm{RP}=2,4$ \\
\hline Tidak & 14 & 31,1 & 31 & 68,9 & 45 & 100 & $(1,0-5,6)$ \\
\hline
\end{tabular}

Berdasarkan data di tabel menunjukkan bahwa dari 53 responden yang menyatakan ada dukungan keluarga yang memiliki motivasi positif sebanyak 28 responden $(52,8 \%)$ dan responden yang memiliki motivasi negatif sebanyak 25 responden $(47,2$ $\%)$. Dari 45 responden yang menyatakan tidak ada dukungan keluarga menunjukkan responden yang memiliki motivasi positif sebanyak 14 responden $(31,1 \%)$ dan responden yang memiliki motivasi negatif sebanyak 31 responden (68,9\%).
Ada hubungan antara dukungan keluaraga dengan motivasi ibu karena Nilai P.Value $=0,040$. Nilai $R P=2,4$ menunjukkan dukungan keluarga merupakan faktor risiko motivasi kehadiran ibu, artinya ibu yang tidak ada dukungan keluarga akan berisiko sebesar 2,4 kali tidak hadir dalam penyuluhan gizi dibandingkan dengan ibu yang ada dukungan keluarga. 
Hubungan Peran Tenaga Kesehatan dengan Motivasi Kehadiran Ibu dalam Penyuluhan Gizi Balita

\begin{tabular}{|c|c|c|c|c|c|c|c|}
\hline \multirow{3}{*}{$\begin{array}{l}\text { Peran Tenaga } \\
\text { Kesehatan }\end{array}$} & \multicolumn{4}{|c|}{ Motivasi } & \multicolumn{2}{|c|}{ Jumlah } & \multirow[t]{2}{*}{$P$. Value $=0,001$} \\
\hline & \multicolumn{2}{|c|}{ Positif } & \multicolumn{2}{|c|}{ Negatif } & & & \\
\hline & $\mathrm{n}$ & $\%$ & $\mathrm{n}$ & $\%$ & f & $\%$ & \\
\hline Ada & 30 & 60,0 & 20 & 40,0 & 50 & 100 & $\mathrm{RP}=4,5$ \\
\hline Tidak & 12 & 25,0 & 36 & 75,0 & 48 & 100 & $(1,8-10,6)$ \\
\hline
\end{tabular}

Berdasarkan data ditabel menunjukkan bahwa dari 50 responden yang menyatakan ada peran tenaga kesehatan yang memiliki motivasi positif sebanyak 30 responden $(60,0 \%)$ dan motivasi negatif sebanyak 20 responden $(40,0 \%)$. dari 48 responden yang menyatakan tidak ada dukungan keluarga yang memiliki motivasi positif sebanayak 12 responden $(25,0 \%)$ dan

\section{PEMBAHASAN}

\section{Hubungan Pengetahuan Dengan Motivasi Kehadiran Ibu pada Penyuluhan Gizi}

Menurut Supriasa (2012), tujuan diadakan penyuluhan gizi yaitu untuk meningkatkan kesadaran gizi dalam masyarakat. Karena itu pula penting adanya pengetahuan pada masyarakat atau khususnya bagi untuk memberikan gizi terhadap balita agar balita tumbuh sehat. Sedangkan menurut Notoatmodjo (2012) perilaku pemeliharaan atau pencarian kesehatan dapat dilakukan dengan meningkatkan pengetahuan seseorang. Karena pengetahuan sebagaimana disebutkan oleh Bloom dalam Notoatmodjo (2012) merupakan wilayah kognitif dalam membentuk tindakan seseorang.

Asumsi peneliti berkaitan dengan masih adanya sebagian responden yakni ibu balita yang memiliki pengetahuan kurang tentang pentingnya hadir dalam penyuluhan gizi dikarenakan ibu tidak mengetahui kandungan zat gizi yang terdapat dalam yang memiliki motivasi negatif sebanyak 36 responden $(75,0 \%)$.

Ada hubungan antara peran tenaga kesehatan dengan motivasi karena nilai P.Value $=0,001$. Nilai RP $=4,5$, artinya ibu yang menyatakan tidak ada peran tenaga kesehatan akan berisiko sebesar 4,5 kali tidak hadir dalam penyuluhan gizi dibandingkan dengan ibu yang menyatakan ada peran tenaga kesehatan.

makanan yang diberikan kepada balita. Selain itu, ibu juga kurang tahu bahwa apabila balita kekurangan zat gizi seperti karbohidrat, protein, lemak dan mineral akan menyebabkan balita akan menderita gizi buruk. Menurut peneliti kurang pengetahuan tentang pentingnya hadir dalam penyuluhan gizi dikarenakan ibu tidak pernah mendapat informasi dari kader posyandu atau petugas kesehatan puskesmas sehingga ibu memiliki motivasi negatif mengenai pentingnya hadir dalam penyuluhan gizi.

Penelitian ini sejalan dengan penelitian yang dilakukan oleh Imbar (2016) bahwa berdasarkan hasil penelitian yang dilakukan menunjukkan distribusi tingkat pengetahuan responden yaitu pengetahuan baik 36 reponden $(60 \%)$ dan pengetahuan kurang 24 responden (40\%). Hasil analisis statistik menggunakan uji chi-square diperoleh nilai P.Value $=0,002$ artinya terdapat hubungan antara pengetahuan dengan motivasi kehadiran ibu dalam 
penyuluhan gizi di Wilayah Kerja Puskesmas Kakaskasen Kecamatan Tomohon Utara Kota Tomohon.

Penelitian lain yang sejalan adalah penelitian yang dilakukan oleh Yulita (2017) bahwa berdasarkan analisis statitik menggunakan uji chi-square diperoleh nilai P.Value sebesar $=0,000$ artinya ada hubungan antara pengetahuan dengan motivasi ibu hadir dalam penyuluhan gizi di Puskesmas Simpang Baru. Sedangkan dari penelitian yang telah dilakukan oleh Mahardika (2016) bahwa berdasarkan hasil penelitian yang telah dilakukan diketahui nilai P.Value $=$ 0,003 artinya ada hubungan pengetahuan di Desa Gedongan Kecamatan Colomadu Kabupaten Karanganyar.

\section{Hubungan Sikap Dengan Motivasi Kehadiran Ibu Pada Penyuluhan Gizi}

Penyuluhan merupakan bagian dari perilaku individu yang diperlukan dalam upaya meningkatkan kesehatan masyarakat. Karena dalam perilaku tersebut, sikap merupakan salah satu domain terpenting apabila individu ingin memperbaiki status kesehatannya. Menurut Sasmito (2010) kurang gizi pada balita akan berdampak pada pertumbuhan balita baik pertumbuhan fisik, mental dan kecerdasan. Kurang gizi juga dikhawatirkan dapat mempengaruhi angka kejadian kematian pada balita. Karena itu, penting bagi ibu untuk hadir ke penyuluhan gizi, karena dengan hadirnya ibu ke penyuluhan gizi akan dapat meningkatkan derajat kesehatan masyarakat dan mempertahankan gizi baik.

Asumsi peneliti berkaitan dengan masih ada sebagian responden atau ibu balita yang memiliki sikap negatif berkaitan motivasi kehadiran ibu dalam penyuluhan gizi dikarenakan ibu sibuk bekerja atau mengurus rumah tangga dan sebagian yang lain beralasan bahwa lokasi penyuluhan gizi jauh dari tempat ibu balita berdomisili. Di samping itu, sikap ibu balita dipengaruhi oleh pengetahuan yang kurang baik dimana ibu kurang mengetahui tentang manfaat gizi bagi pertumbuhan balita. Kalau pun ada ibu yang mengetahui manfaat gizi, namun sikap ibu cenderung menunjukkan pada belum adanya mempraktikkan pola makan bergizi bagi balita.

Penelitian ini sejalan dengan penelitian Reihana (2012) bahwa berdasarkan hasil penelitian yang telah dilakukan menunjukkan ibu dengan sikap negatif untuk hadir penyuluhan gizi pada balitanya ke Posyandu yaitu $73,1 \%$ atau tinggi dibanding responden dengan sikap positif yaitu $24,9 \%$. Hasil analisis statistik menggunakan uji chi-square diperoleh nilai P.Value sebesar 0,015 artinya terdapat hubungan antara sikap ibu dengan motivasi kehadiran ibu dalam penyuluhan gizi di Wilayah Kerja Puskesmas Panjang Provinsi Lampung.

Penelitian selanjutnya adalah penelitian yang dilakukan oleh Maimun (2016) bahwa berdasarkan hasil uji chisquare diperoleh nilai P.Value sebesar 0,004 artinya terdapat hubungan antara sikap dengan motivasi kehadiran ibu dalam kegiatan penyuluhan gizi di Wilayah Kerja Puskesmas Pagak Kabupaten Malang. Penelitian lain juga dilakukan oleh Juwita (2016) bahwa berdasarkan hasil penelitian yang telah dilakukan diperoleh nilai P.Value sebesar 0,000 artinya terdapat hubungan antara sikap ibu dengan motivasi kehadiran ibu dalam penyuluhan gizi di di Puskesmas Simpang Baru.

\section{Hubungan Dukungan Keluarga Dengan Motivasi Kehadiran Ibu Pada Penyuluhan Gizi}


Menurut Notoatmodjo (2012), dukungan keluarga merupakan faktor penguat timbulnya perilaku kesehatan dalam masyarakat. Dalam hal tersebut dapat diartikan bahwa ibu yang sudah tahu manfaat penyuluhan gizi dan terdapat fasilitas pelayanan kesehatan untuk balita di Posyandu atau puskesmas, tetapi ibu tetap tidak hadir ke penyuluhan gizi, dengan alasan keluarga tidak atau kurang mendukung ibu untuk dapat ke penyuluhan gizi.

Asumsi peneliti berkaitan dengan masih ada sebagian responden atau ibu balita yang tidak hadir ke penyuluhan gizi balita yang berkaitan dengan tidak ada dukungan keluarga bahwa sebelumnya keluarga dari ibu balita tidak pernah mengikuti penyuluhan gizi. Hal tersebut erat kaitannya dengan bahwa ketika datang ke penyuluhan gizi, maka memenuhi kebutuhan gizi sebagaimana anjuran dari kader atau petugas kesehatan akan memberatkan bagi keluarga karena masalah biaya yang mana sebagian dari keluarga kurang mampu untuk memberikan gizi yang cukup bagi balita.

Penelitian ini sejalan dengan penelitian yang dilakukan oleh Novianti (2016) bahwa berdasarkan hasil penelitian yang telah dilakukan menunjukkan keluarga yang memberikan dukungan kepada ibu hadir penyuluhan gizi ke posyandu sebesar 42,8 \% dan sebaliknya keluarga yang kurang memberikan dukungan kepada ibu untuk hadir penyuluhan gizi ke posyandu sebesar 58,2 \%. Hasil analisis statistik menggunakan uji chsquare diperoleh nilai P.Value $=0,000$ artinya terdapat hubungan antara dukungan keluarga dengan motivasi kehadiran ibu untuk hadir penyuluhan gizi di Wilayah Kerja UPTD
Puskesmas Wiradesa Kabupaten Pekalongan.

Penelitian ini sejalan dengan penelitian yang dilakukan oleh Sartika bahwa dari hasil analisis data menggunakan uji chi-square diperoleh nilai P.Value sebesar 0,000 artinya terdapat hubungan antara dukungan keluarga dengan motivasi ibu hadir dalam penyuluhan gizi di Wilayah Kerja Puskesmas Gondomanan Yogyakarta. Selanjutnya adalah penelitian yang dilakukan oleh Ratnawati (2015) dalam penelitiannya bahwa dari hasil penelitian yang dilakukan menunjukkan ada hubungan antara dukungan keluarga dengan motivasi ibu hadir dalam penyuluhan gizi balita di Mojodanu Kecamatan Ngusikan Kabupaten Jombang.

\section{Hubungan Peran Tenaga Kesehatan Dengan Motivasi Kehadiran Ibu Pada Penyuluhan Gizi}

Dari segi kesehatan masyarakat, agar ibu datang memeriksakan kesehatan balitanya atau untuk dapat hadir dalam kegiatan penyuluhan kesehatan, harus dapat terakses ataupun terjangkau sarana dan prasarana atau fasilitas kesehatan. Peran tenaga kesehatan dalam meningkatkan derajat kesehatan ibu dan anak melakukan evaluasi program kesehatan guna mendorong kesehatan ibu dan anak secara berkesinambungan (Notoatmodjo, 2012).

Asumsi peneliti berkaitan masih adanya sebagian ibu yang menyatakan kurang peran tenaga kesehatan terkait dengan kehadiran ibu dalam penyuluhan gizi bahwasannya ibu tidak pernah mendapat sosialisasi tentang penyuluhan gizi. Selain itu, kurang informasi yang diberikan oleh tenaga kesehatan, membuat ibu kurang motivasi untuk hadir ke penyuluhan 
gizi. Asumsi lainnya, menurut peneliti adalah ibu yang kurang mendapatkan sosialisisi juga dikarenakan faktor ibu yang jarang mengikuti kegiatankegiatan yang dilaksanakan oleh Puskemas meskipun sudah diberitahukan oleh kader-kader kesehatan yang ada di desa tempat ibu berdomisili.

Penelitian ini sejalan dengan penelitian yang dilakukan oleh Sistiarani (2013) bahwa dari hasil penelitian yang telah dilakukan menunjukkan ibu yang menyatakan ada peran tenaga kesehatan sebesar $62,8 \%$ sebaliknya ibu yang menyatakan tidak ada peran tenaga kesehatan sebesar $38,2 \%$. Hasil analisis statistik menggunakan uji chi-square diperoleh nilai P.Value $=0,001$ artinya ada hubungan antara peran tenaga kesehatan dengan motivasi ibu ikut serta dalam kegiatan penyuluhan gizi pada balita di Wilayah Kerja Puskesmas Kalibagor Kabupaten Banyumas.

Penelitian ini sejalan dengan penelitian yang dilakukan oleh Wahyningsih (2014) dalam penelitiannya bahwa dari hasil analisis statistik menggunakan uji chi-sqauare diperoleh nilai P.Value $=0,007$ artinya terdapat hubungan antara dukungan kader kesehatan dengan motivasi ibu hadir dalam penyuluhan gizi Di Wilayah Kerja Puskesmas Sumber Wringin Kabupaten Bondowoso. Selanjutnya adalah penelitian yang dilakukan oleh Paridah (2013) bahwa dari penelitian yang dilakukan menunjukkan hasil analisis statistik menggunakan uji chi-square diperoleh nilai P.Value sebesar 0,011 artinya terdapat hubungan peran tenaga kesehatan dengan motivasi kehadiran ibu dalam penyuluha gizi di Wilayah Kerja Puskesmas Pamandati Kabupaten Konawe Selatan.

\section{KESIMPULAN}

1. Ada hubungan Pengetahuan dengan motivasi yang menunjukkan nilai $P$. Value $=0,013$ dan Nilai $R P=3,1$ yang artinya ibu yang memiliki penegtahuan kurang akan berisiko sebesar 3,1 kali tidak hadir dalam penyuluhan gizi dibandingkan dengan ibu yang memiliki pengetahuan baik.

2. Terdapat hubungan anatara sikap dengan motivasi ibu karna Nilai P.Value $=0,001$. Nilai $R P=4,2$ menunjukkan sikap merupakan faktor risiko motivasi kehadiran ibu, artinya ibu yang memiliki sikap negatif akan berisiko sebesar 4,2 kali tidak hadir dalam penyuluhan gizi dibandingkan dengan ibu yang memiliki sikap positif.

3. Ada hubungan antara dukungan keluaraga dengan motivasi ibu karena Nilai P.Value $=0,040$. Nilai $\mathrm{RP}=2,4$ menunjukkan dukungan keluarga merupakan faktor risiko motivasi kehadiran ibu, artinya ibu yang tidak ada dukungan keluarga akan berisiko sebesar 2,4 kali tidak hadir dalam penyuluhan gizi dibandingkan dengan ibu yang ada dukungan keluarga.

4. Ada hubungan antara peran tenaga kesehatan dengan motivasi karena nilai $\mathrm{P}$. Value $=0,001$. Nilai $\mathrm{RP}=$ 4,5 , artinya ibu yang menyatakan tidak ada peran tenaga kesehatan akan berisiko sebesar 4,5 kali tidak hadir dalam penyuluhan gizi dibandingkan dengan ibu yang menyatakan ada peran tenaga kesehatan. 


\section{SARAN}

1. Disarankan kepada ibu balita untuk mengikuti berbagai kegiatan yang dilaksanakan oleh Posyandu khususnya mengikuti penyuluhan gizi agar ibu memiliki pengetahuan mengenai pentingnya dan manfaat membawa balita keposyandu sehingga dengan pengetahuan yang baik tersebut dapat meningkat pula sikap positif ibu terhadap penyuluhan gizi yang dilaksanakan oleh kader Posyandu.

2. Disarankan kepada keluarga untuk dapat memberikan dukungan agar ibu memiliki motivasi yang baik sehingga ibu dapat hadir mengikuti kegiatan penyuluhan gizi yang dilaksanakan oleh Posyandu.

3. Disarankan kepada Puskesmas untuk dapat meningkatkan peran kader kesahatan dengan cara memberikan bimbing tentang mensosialisikan penyuluan gizi kepada ibu balita dengan mendatangi langsung rumah ibu balita untuk memberikan motivasi, menjelaskan tujuan dan manfaat dan pentingnya ibu datang ke penyuluhan gizi yang dilaksanakan oleh Posyandu.

\section{DAFTAR PUSTAKA}

Almatizer. 2010. Prinsip Dasar Ilmu Gizi. Gramedia Pustaka Utama. Jakarta.

Andriani dan Wijatmadi. 2012. Peranan Gizi Dalam Siklus Kehidupan. Kencana. Jakarta.

Arikunto. 2011. Prosedur Penelitian, Suatu Pendekatan Praktik. PT. Rineka Cipta. Jakarta.

Baliwati. 2014. Pengantar Pangan dan Gizi. Penebar Swadaya. Jakarta.

Dahlia. 2012. Pengaruh Pendekatan Positive Deviance Terhadap
Peningkatan Status Gizi. Jurnal

Puskesmas Binamu. Sulawesi Selatan.

Depkes RI. 2010. Pedoman Penyuluhan Bagi Petugas Kesehatan. Depkes RI. Jakarta. . 2012. Kebijakan Pusat Kesehatan Masyarakat. Depkes RI. Jakarta. . 2010. Petunjuk Pemantauan Pertumbuhan Balita. Depkes RI. Jakarta.

Dinkes Aceh. 2012. Profil Kesehatan Provinsi Aceh Tahun 2012. Banda Aceh.

. 2014. Profil Kesehatan Provinsi Aceh Tahun 2014. Banda Aceh.

Dinkes Aceh Barat. 2015. Profil Kesehatan Kabupaten Aceh Barat Tahun 2015. Banda Aceh.

Hidayat, Alimul. 2010. Metode Penelitian Kesehatan. Paradigma Kuantitatif. Healt Books Publishing. Surabaya.

Lucie. 2014. Ilmu Gizi untuk Keperawatan dan Gizi Kesehatan. Nuha Medika Yogyakarta.

Imbar, P. Faktor-Faktor Yang Berhubungan Dengan Motivasi Kehadiran Ibu Dalam Penyuluhan Gizi Wilayah Kerja Puskesmas Kakaskasen Kecamatan Tomohon Utara Kota Tomohon. Jurnal Vol.4 No.1 2016 ISSN 2339-1731 Fakultas Kesehatan Masyarakat Universitas Diponegoro.

Mahardika. 2016. Hubungan Pengetahuan Ibu Tentang Gizi Dan Tingkat Kehadiran Anak Balita Di Posyandu Dengan Status Gizi Anak Balita Di Desa Gedongan Kecamatan Colomadu Kabupaten Karanganyar. Jurnal Vol.2 No.1 
Tahun 2016 ISSN 1820-1927

Program Studi Ilmu Gizi Fakultas Ilmu Kesehatan Universitas Muhammadiyah Surakarta.

Maimun, Neni. 2016. Hubungan Sikap Dengan Motivasi Ibu Memeriksakan Balita Ke Posyandu Wilayah Kerja Puskesmas Pagak Kabupaten Malang. Jurnal Nursing News Volume 1, Nomor 1, 2016 ISSN 2111-1722 Universitas Tribhuwana Tunggadewi Malang.

Moehji, S. 2013. Ilmu Gizi Penanggulangan Gizi Buruk. Papas Sinar Siinanti. Jakarta.

Notoatmodjo. 2010. Promosi Kesehatan dan Ilmu Perilaku. Rineka Cipta. Jakarta.

Notoatmodjo. 2012. Promosi Kesahatan dan Perilaku Kesehatan. Edisi Revisi 2012. PT. Rineka Cipta. Jakarta.

Novianti. 2016. Faktor yang berhubungan dengan Perilaku dan dukungan keluarga dengan motivaasi ibu untuk hadir ke Posyadu di Wilayah Kerja UPTD Puskesmas Wiradesa Kabupaten Pekalongan. Jurnal Ilmiah Kesehatan Vol 7 No. 2 Tahun 2016 ISSN 2087-7031 Fakultas Kesehatan Masyarakat Universitas Indonesia.

Sandjaja. 2010. Selingan Makanan Untuk Balita. Gramedia Pustaka Utama. Jakarta.

Santoso. 2012. Kesehatan dan Gizi. Rineka Cipta. Jakarta.

Santjaka. 2011. Statistik Untuk Penelitian Kesehatan 1. Nuha Medika. Yogyakarta.

Sartika. 2016. Hubungan antara Dukungan Suami dengan Motivasi
Ibu Balita Berkunjung ke Posyandu di Wilayah kerja Puskesmas Gondomanan Yogyakarta. Jurnal Kesmas Vol 1 No. 2 tahun 2016. ISSN 19112192 Universitas Muhammadiyah Yogyakarta.

Sasmito. 2012. Penilaian Status Gizi. EGC. Jakarta.

Sistiarani. 2013. Hubungan Peran Tenaga Kesehatan Dengan Motivasi Ibu Ikut Serta Dalam Kegiatan Penyuluhan Gizi di Wilayah Kerja Puskesmas Kalibagor Kabupaten Banyumas. Jurnal Kesmas Vol.8 No.2 ISSN 2339-1731 Tahun 2013. FKM Universitas Semarang.

Soejtiningsih. 2010. Tumbuh Kembang Anak. EGC. Jakarta.

Soekirman. 2010. Ilmu Gizi dan Aplikasinya. Dirjen Pendidikan Tinggi Depertemen Pendidikan Nasional. Jakarta.

Suhadrjo. 2013. Berbagai Cara Pendidikan Gizi. Bumi Aksara. Jakarta.

Supariasa. 2012. Kesehatan Anak Balita. Fajar Lentera. Bandung.

Ratnawati. 2015. Faktor-Faktor Yang Berhubungan Dengan Motivasi Ibu Hadir Ke Penyuluhan Gizi Ke Posyandu Di Desa Mojodanu Kecamatan Ngusikan Kabupaten Jombang. Jurnal Kesmas Volume 2 Nomor 1 tahun 2015 Keperawatan STIKES PEMKAB Jombang.

Reihana. 2012. Faktor yang mendorong partisipasi dan motivasi ibu hadir dalam penyuluhan gizi di Wilayah Kerja Puskesmas Panjang Provinsi Lampung. Jurnal Vol. 2 No. 22012 ISSN 1432-1571 Fakultas 
Kesehatan Masyarakat Universitas Semarang.

Riyanto. 2011. Pengolahan dan Analisis Data Kesehatan. (Dilengkapi Uji Validitas dan Realibilitas serta Aplikasi Program SPSS). Nuha Medika. Yogyakarta.

Yulita. 2017. Faktor-Faktor yang Berhubungan Dengan Motivasi Ibu Hadir Dalam Penyuluhan Gizi di Wilayah Kerja puskeSmas Simpang Baru. Jurnal JOMIS
(Journal Of Midwifery Science) PISSN : 2549-2543 Vol 1. No.2, Juli 2017 E-ISSN : 2579-7077.

Wahyuningsih. 2014. Dukungan Kader Kesehatan Dengan Motivasi Ibu Hadir Dalam Penyuluhan Gizi Di Wilayah Kerja Puskesmas Sumber Wringin Kabupaten Bondowoso. Jurnal Vol 1 No 2 Tahun 2014 ISSN: 1132-1241 FKM Universitas Semarang. 